\title{
Antimicrobial Activity of Citrullus Colocynthis (Bitter Mellon)
}

\author{
Omme Hany and Asia Neelam* \\ Institute of Environmental Sciences, University of Karachi, Pakistan \\ *Corresponding author: Asia Neelam, Institute of Environmental Sciences, University of Karachi, Pakistan
}

\begin{tabular}{|c|c|}
\hline ARTICLE INFO & Abstract \\
\hline Received: 蔧 May 13, 2020 & In the present study Citrullus colocynthis (L.) were studied on several types of \\
\hline Published: May 27, 2020 & $\begin{array}{l}\text { pathogenic bacteria and fungi and their inhibitory power compared with the standard } \\
\text { drugs Imipenem and Miconazole. Among the gram-positive bacteria Staphylococcus }\end{array}$ \\
\hline $\begin{array}{l}\text { Citation: Omme H, Asia N. Antimicrobi- } \\
\text { al Activity of Citrullus Colocynthis (Bitter } \\
\text { Mellon). Biomed J Sci \& Tech Res 27(5)- } \\
\text { 2020. BJSTR. MS.ID.004576. }\end{array}$ & $\begin{array}{l}\text { while among the gram-positive bacteria Escherichia coli show the excellent inhibition } \\
\text { effectagainst Ethyl acetate extract ( } 18 \pm 0.4 \text { ). For the Antifungal test six pathological fungi } \\
\text { selected (Trichophyton longifusus, Candida albicans, Aspergillus flavus, Microsporum } \\
\text { canis, Fusarium solani and Candida glabrata), in which the specie of Candida (C. albicans } \\
\text { and C.glabrata) show significant level of inhibition against methanolic extract ( } 68 \pm 0.2 \text { ) }\end{array}$ \\
\hline Keywords: Citrullus colocynthis; Cucurbi- & and $(62 \pm 0.2)$ \\
\hline
\end{tabular}

ical; Rheumatism

\section{Introduction}

Medicinal plants consider to be as an important therapeutic agent for human beings as its contain multiple phytochemical and antioxidant compound, hence there is an increasing demand day by day for more drugs of plant origin [1,2]. Citrullus colocynthis belongs to the family of melon (cucurbitaceous) with the size 1530 , about 7-10 cm in diameter, green with undulate yellow stripes, becoming yellow all over when dry .This medically important plant found in sandy land of Northern west ,the sind Punjab ,Souther India Tropical Asia and Africa, or widely distributed in the region of Saharo-Arabian and the Mediteranean [3-5]. Many phytochemical active compound are present in the fruits of Citrullus colocltnthis including colocythin alkaliods, saponin bitter resins ,colocynthidin and glycosides like cucurbitacin E [5-7]. In traditional medicine, the fruit of Citrullus colocynthis was recommended for the cure of fever, Jaundice, Ameninhea, constipation, killing intestinal parasite, rheumatism, ascites, snakebite, tumors especially abdominal region, Cancers, diabetics and leukemia [8,9]. The present study was design to evaluate the antimicrobial effect of Citrullus colocynthis on selected bacteria and fungi.

\section{Method and material}

\section{Collection and Identification}

The whole plant was collected from Cholistan Desert near Bahawalpur, and futher identify by the Cholistan Institute of Desert Studies (CIDS), Islamia University of Bahawalpur, where a voucher specimen has been deposited. Later, the samples were transferred to University of Karachi, Pakistan for biological analysis.

\section{Extraction and Culture Media}

Successive hexane, chloroform, ethyl acetate, butanol, methanol, and water respectively were used for the Citrullus colocynthis extraction. Three strains of Gram-positive bacteria (Bacillus subtilis, Shigella flexneri, Staphylococcus aureus) and three strains of Gram-negative bacteria (Escherichia coli Pseudomonas aeruginosa, Salmonella typhi) were subjected for laboratory analysis. Antifungal test done on six pathological fungi (Trichophyton longifusus, Candida albicans, Aspergillus flavus, Microsporum canis, Fusarium solani and Candida glabrata) The antibacterial activity done by agar well diffusion method [10], and antifungal activity by agar well diffusion 
method [11]. All the test were conducted in sterilized environment to avoid contamination. For positive control Imipenem (10 ug/ disc) were used for antibacterial and Miconazole (10 ug/disc) for antifungal activity. Subjective test was performed in triplets to minimize the error.

\section{Result and Discussion}

The medical used of the herbal plants for the remediation of infectious disease is not new. The preliminary studies of antimicrobial activity of Citrullus colocynthis reported in this paper. According to the result in Table 1 , at a certain level the antimicrobial activity of Citrullus colocynthis at different solvents comparable to that of commercial antibiotic and antifungal drugs i.e. Imipenem and Miconazole, respectively. On Salmonella typhi causative agent of typhoid fever, ethyl acetate (12 \pm 0.2$)$ and methanolic (10 \pm 0.1$)$ extracts influence more, then the other extracts. On Shigella flexneri the effect of Citrullus colocynthis is poor, the only two extract (Methanolic and ethyl acetate) suppress the growth, However the remaining extract show no zone of inhibition. Among the gram positive bacteria Staphylococcus aureus show significant growth inhibition effect against methanolic extract $(17 \pm 0.2)$, while in gram positive bacteria Escherichia coli show highest zone of inhibition against ethyl acetate extract $(18 \pm 0.4)$.The all strain of bacteria and fungi reported in this study were somehow influence by all the subjective extract except Aqueous Extract (AE),which show no effect in any bacteria and fungi.

Table 1.

\begin{tabular}{|c|c|c|c|c|c|c|c|}
\hline \multirow{2}{*}{$\begin{array}{c}\text { Microorganism } \\
\text { Bacteria }\end{array}$} & \multicolumn{7}{|c|}{ Zone of inhibition diameter (mm) } \\
\hline & ME & HE & CE & EE & BE & $\mathbf{A E}$ & Standard drug \\
\hline & & & & & & & Imipenem \\
\hline Bacillus subtilis & $15 \pm 0.5$ & $5 \pm 0.1$ & $11 \pm 0.2$ & $13 \pm 0.1$ & $8 \pm 0.1$ & NA & $33 \pm 0.8$ \\
\hline Shigella flexneri & $5 \pm 0.2$ & NA & NA & $7 \pm 0.5$ & NA & NA & $27 \pm 0.5$ \\
\hline Staphylococcus aureus & $17 \pm 0.2$ & $8 \pm 0.1$ & $12 \pm 0.5$ & $10 \pm 0.5$ & $8 \pm 0.2$ & NA & $33 \pm 0.1$ \\
\hline Escherichia coli & $16 \pm 0.1$ & $6 \pm 0.5$ & $9 \pm 0.2$ & $18 \pm 0.4$ & $14 \pm 0.5$ & NA & $30 \pm 0.5$ \\
\hline Pseudomonas aeruginosa & $17 \pm 0.2$ & NA & $9 \pm 0.1$ & $15 \pm 0.7$ & $12 \pm 0.1$ & NA & $24 \pm 0.2$ \\
\hline Salmonella typhi & $10 \pm 0.1$ & $7 \pm 0.2$ & NA & $12 \pm 0.2$ & NA & NA & $25 \pm 0.1$ \\
\hline Fungi & & & & & & & Miconazole \\
\hline Trichophyton longifusus & $62 \pm 0.5$ & $15 \pm 0.2$ & $45 \pm 0.1$ & $40 \pm 0.4$ & $10 \pm 0.2$ & NA & $70 \pm 0.1$ \\
\hline Candida albicans & $68 \pm 0.2$ & $10 \pm 0.4$ & $40 \pm 0.5$ & $34 \pm 0.2$ & $16 \pm 0.5$ & NA & $110.8 \pm 0.5$ \\
\hline Aspergillus flavus & $12 \pm 0.1$ & NA & NA & $12 \pm 0.4$ & NA & NA & $20 \pm 0.9$ \\
\hline Microsporum canis & $45 \pm 0.3$ & $10 \pm 0.1$ & $25 \pm 0.5$ & $25 \pm 0.8$ & $8 \pm 0.1$ & NA & $98.4 \pm 0.5$ \\
\hline Fusarium solani & $50 \pm 0.1$ & NA & $38 \pm 0.5$ & $42 \pm 0.2$ & $12 \pm 0.2$ & NA & $73.25 \pm 0.2$ \\
\hline Candida glabrata & $62 \pm 0.2$ & NA & $20 \pm 0.2$ & $17 \pm 0.2$ & $8 \pm 0.1$ & NA & $110.8 \pm 0.5$ \\
\hline
\end{tabular}

All the targeted fungi show excellent response against all the tested material while only one fungi Aspergillus flavus restained by methanolic (ME) and Ethyl Acetate (EE) extract. The specie of Candida (C. albicans and C.glabrata) show significant inhibition activity against methanolic extract $(68 \pm 0.2)$ and $(62 \pm 0.2)$. To the some extend our finding is similar to the study of Marzouk et al whose show the significant effect of fruit of Citrullus colocynthis on Candida spp ,Escherichia coli and Pseudomonas aeruginosa [12]. Citrullus colocynthis contain flavonoids, steroids, alkaloids and terpenoids as an important constituents [9-13]. The plants that contain terpenoids and flavonoids are recommended for the cure of inflammation and microbial infection $[1,13,14]$. Hence we can say that the curative property of this understudy plant is related to their phytochemical molecules. Regarding one of the previous study $[15,16]$ and our study, it was observed that alkaloids were activity present in the ethanolic extracts. Therefore, it will be recommended that to exploit more benefits of $C$. colocynthis the sample should be prepared with ethanol and methanol since alkaloids is known to be effective.

\section{Conclusion}

Infectious disease caused by bacteria, parasites, viruses, and fungi are still the major concern for public health. Now scientists are more concern towards natural products as compared to the synthetics. Hence, Citrullus colocynthis shows excellent inhibition power for most of test microbes and effectivity recommended for control the infection and other disease.

\section{References}

1. Neelam A, Omme Hany, Sherwani S K, Jabeen S, Nangyal H (2014) Phytochemical and bioactivity of commercially available Eucalyptus oil against human pathogen. South Asian Journal of life science 2(1): 8-11.

2. Nair R, Vaghaisya Y, Godvani N, Solanki A, Baluja S, et al. (2008) Antibacterial activity of punica granatum stem. Plant Archies Int J plant Res 8(2): 671-673.

3. Stewart RR (1972) An annotated catalogue of the vascular plants of West Pakistan and Kashmir. Flora of West Pakistan Fakhri Press Karachi.

4. Pravin B, Tushar D, Vijay P, Kishanchnad K (2013) REVIEW ON Citrullus colocynthis IJRPC 3(1): 46-53.

5. Mossa J, Al Yahya M, Al Meshal L (1987) Medicinal plants ol Saudi Arabia. King saud University. 
6. Al Rawi A, Chakravarty HL (1864) Medicinal plants of Iraq. Al yaqath Press.

7. Abdel Hassan, Abdel Barry J, Mohammed S (2000) The hypoglycaemeic and antihlperglycaemic effecL of $\mathrm{C}$ itrullus colocynlhis fruit aqueous extract in normal and alloxan diabetic rabbits. J Ethnopharma 71(1-2) : 325-330.

8. Nadkami K M (1954) lndian material medica.

9. Mhaskar KS (2000) Indian Medicinal Plants.

10. Irobi O N, Moo young, W A Anderson, S O Daramola (1994) Antimicrobial Activity of the bark of Bridelia ferrunginea (Euphobiaceae). Intern J Pharmarog 43(3): 87-90.

11. Perez C, Paul M , Bezique P, C Perez Eid (1990) An Antibiotic assay by the agar well diffusion method. Alta Biomed. 15: 113.

ISSN: 2574-1241

DOI: 10.26717/BJSTR.2020.27.004576

Asia Neelam. Biomed J Sci \& Tech Res

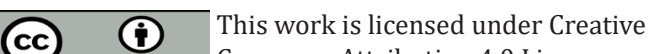

Submission Link: https://biomedres.us/submit-manuscript.php
12. Marzouk B, Marzouk Z, Décor R, Edziri H, Haloui E (2009) Antibacterial and Anticandidal screening of Tunisian Citrullus colocynthis Schrad. from Medenine. J Ethnopharmacol 125(2): 344-349.

13. Okwu DE, C Josiah (2006) Evaluation of the chemical composition of two Nigerian medicinal plants. Afri J Biotech 5(4): 357-361.

14. Nyarko AA, Addy ME (1990) Effects of aqueous extract of Adenia cissampeloides on blood pressure and serum analyte of hypertensive patients. Phytotherapy Res 4(1): 25-28.

15. Trease GE, Evans WC (1982) Phamacognosy 735-738.

16. Zee cheng Rk (1997) Anticancer research on Loranthaceae plants. Drugs Future 22 (5): 515-530.

BIOMEDICAL
RESEARCHES $\quad$\begin{tabular}{l} 
Assets of Publishing with us \\
\hline
\end{tabular}

